\title{
INVESTMENT STRATEGY AS A CONDITION FOR PURSUING A COMPANY'S GENERAL STRATEGY
}

\author{
Beata Ślusarczyk, Assistant professor,jagoda@zim.pcz.czest.pl \\ Czestochowa University of Technology, Management Faculty
}

\begin{abstract}
In order to pursue general strategy of a company there have to be formulated specific strategies, focusing on the area of the company's operation which is responsible for its success. According to many economists, the investments and the properly designed investment strategy condition development of a company. Confirming this thesis is one of major objectives of the following paper, which also sets out to identify factors conditioning activity in the sphere of investment in a company's strategy, and discusses various types of investment strategies.
\end{abstract}

Investments, being a fundamental factor in development of companies, are an integral part of their investment strategies and, moreover, often guarantee effective pursuing of the general strategy adopted by a company.

A company's strategy is, most frequently, at one with a broad scheme of establishing and attaining its objectives. However, there exist significant disparities between the practical implementation and the design of a company's strategy, beginning with complicated economic programs, through overall objectives of a company's restructuring, ending with designing a strategy that remains appropriate in spite of changing external and internal conditions of the company's operation. Apart from ascertaining a sufficient level of competence and experience of the company's executives, a condition that has to be met if the company is to remain on the market and develop, is designing such a strategy that will perform all the functions listed above. $[10$, p. 41$]$

The most important objective of the company's general strategy is increasing its market value. Attaining this objective is possible thank to subordinate specific strategies (drawing 1) 


\section{ECONOMIC AND SOCIAL SURROUNDINGS}

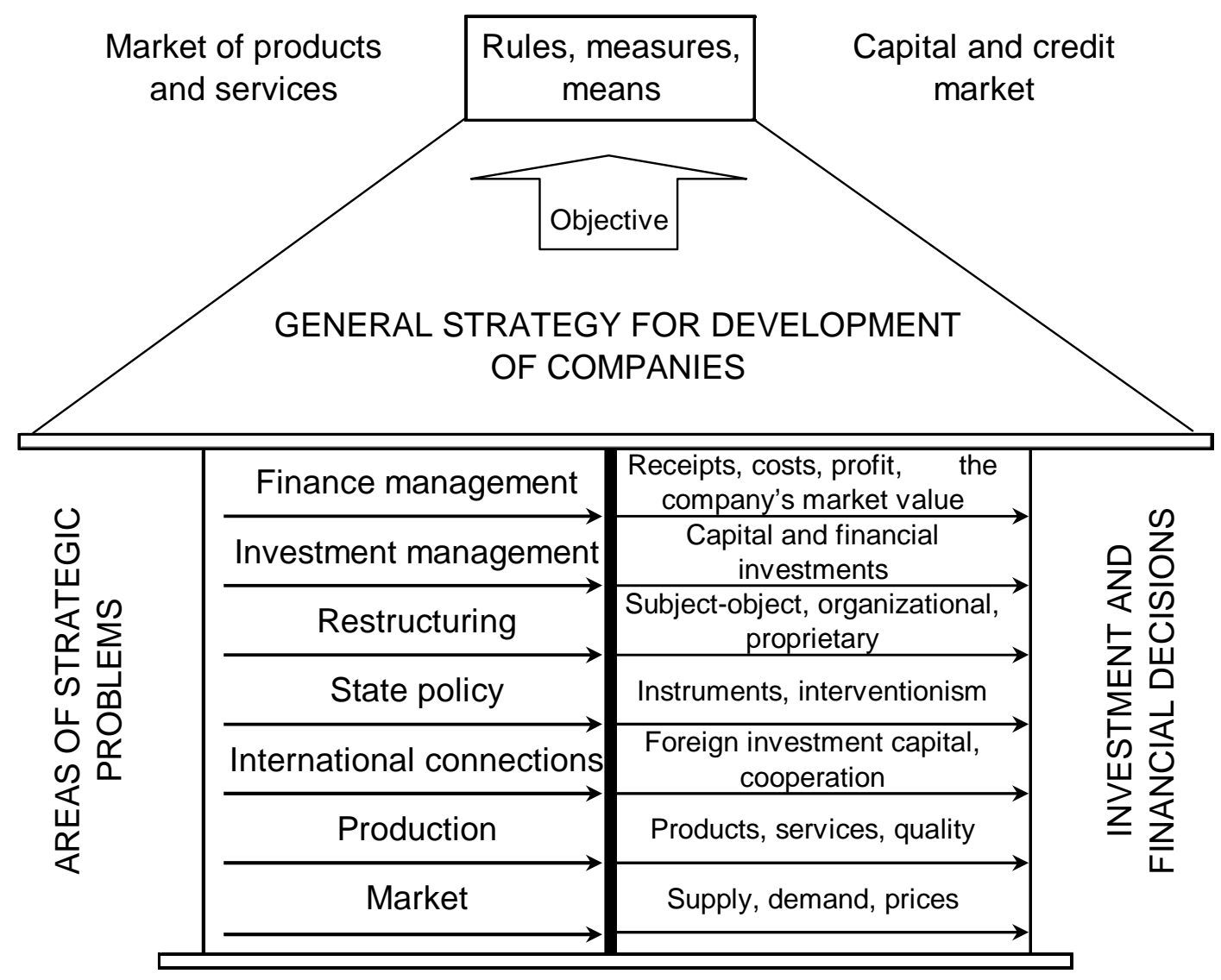

Drawing 1 Elements of designing the general strategy of company's development

Source: E. Ostrowska, Ryzyko projektów inwestycyjnych, PWE, Warszawa 2002, s. 15

In order to attain the fundamental objective of the general strategy, a company formulates a number of additional specific strategies. They include, among others, a strategy for company restructuring, which constitutes such a change of the concepts and practical solutions implemented in the company's functioning that it gains a good starting point in competing with other companies on both the domestic and foreign market [10, p.251]; a strategy for finance management, identified as aiming at a proper choice of assets and liabilities in order to maximize their value; and a marketing strategy being a means of preparing and conducting a research concerning future structure of product and service demand, and its filling by creating supply. Investment strategy, i.e. the strategy of allocating capital, is also a specific strategy. [8, p. 15] Above all, it concerns capital and financial investments connected with capital market, as well as non-pecuniary investments (e.g. purchase of patents and licenses). A well-designed strategy is vital especially while choosing sources and conditions of financing endeavors connected with company development.

Thus, investment endeavors condition, to a significant extent, the pursuing of global strategies of companies, since they allow for implementing the tactics of both expansion and stagnation. Positive effects in company development cannot be achieved without expenditure on 
investments. Investments create indispensable capability in the spheres of production, services, trade, et cetera, facilitating the production of goods, providing services, and fulfilling other needs. Therefore, a global company strategy justifies the need for formulating and pursuing an investment strategy. [11, p. 167]

According to B. Woźniak-Sobczak, the factors which determine the value of a company are responsible for the fact that investment strategy is company's basic strategy. "Its essence is a collection of far-reaching decisions concerning the most beneficial sources, times and conditions of acquiring financial capital (financial investments), its transfer into production capital (capital investments) and directed allocation of this capital which, as a result, will make it possible for the company to attain its vital objective" [14, p. 60, translation mine].

The objectives of investment strategy are the resultant of global strategies of companies. Establishing the increase of its market value as the company's strategic objective results in the fact that the criterion of investment decisions derives from its strategic objective and is specified by the maximum increase of the profit from the invested capital, while accepting a certain level of risk. [12, p.74]

Identifying proper investments and determinants of the processes of their design and implementation is especially important. These determinants ought to be considered as ones that determine investment activity in company development strategy. (drawing 2).

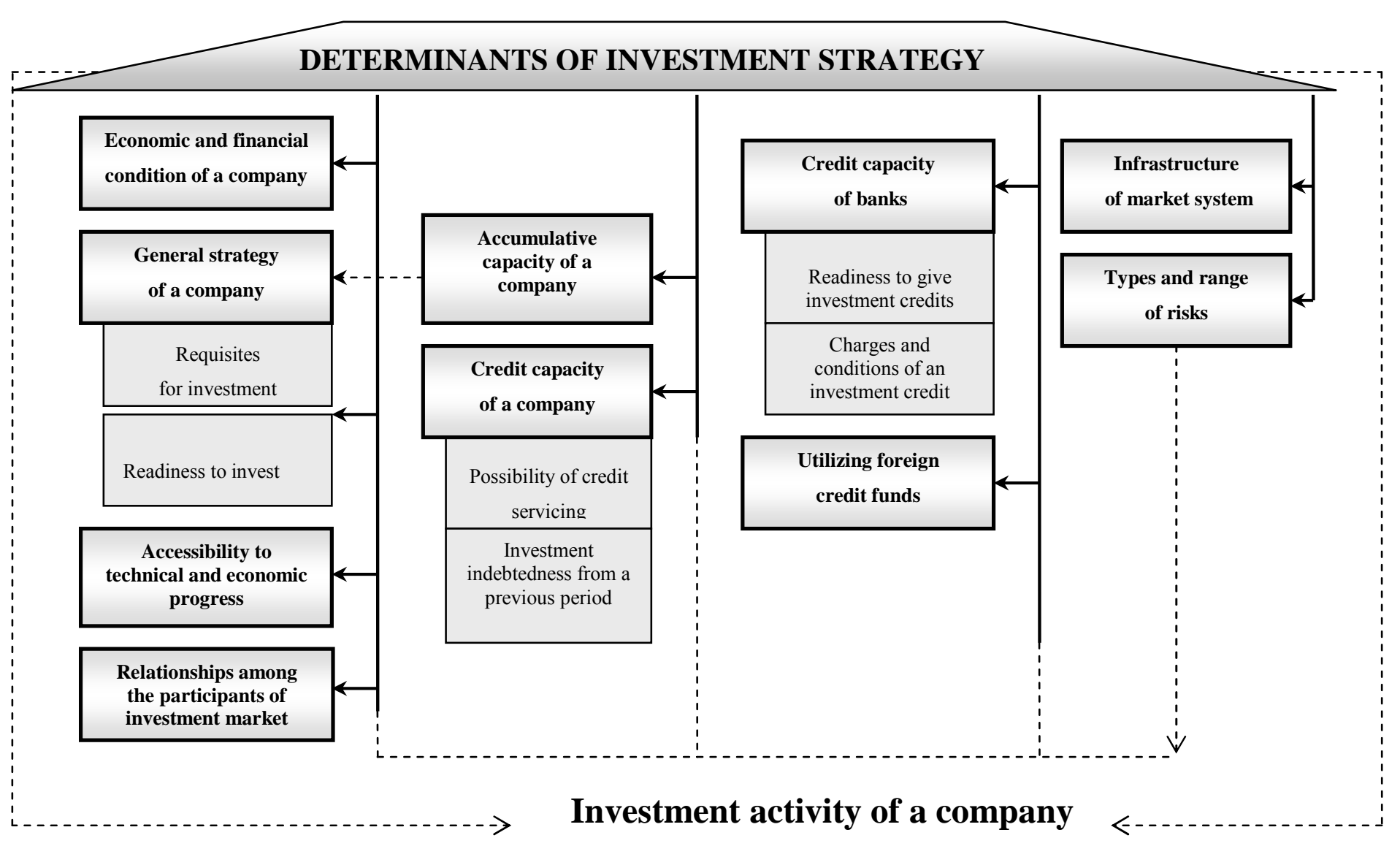

Drawing 2. Basic determinants of investment strategy in company development

Source: E. Ostrowska, Ryzyko projektów inwestycyjnych, PWE, Warszawa 2002, s. 23 
Certainly, general strategy is to a serious extent responsible for the choice of investment strategy, as it determines whether a company ought to name development as its objective. No less important is the economic and financial condition of a company, which determines its financial standing, being the result of economic decisions made by the given business entity, with which its future perspectives are connected. [9, p.31] Depending on their financial condition, companies make large, risky investments or minor, low-risk investments which involve little expenditure. Financial condition of a company depends, to a large extent, on its accumulative capacity, which mirrors its capacity for making profit and generating cash. According to publications on banking, a company's financial condition is tightly connected with the evaluation of credit capacity of the potential borrower. As for banks, company capacity for up-to-date servicing and repayment of investment credit is a basic condition for giving such credits. [6, p. 117] Investment strategy of companies is also conditioned by relationships among participants of the investment market, whose activities create investment processes. These participants include investors, designers, executors, financial and legal institutions, and environmentalist organizations. Their activity, combined with mechanisms and regulations conditioning a company's development activity, directly influence its investment strategy.

Investments made by a company are connected with the risk of suffering serious losses, and often even with the loss of the invested capital. The risk connected with investing is the result of uncertainty concerning different aspects of the process, such as the amount of time necessary for pursuing an investment and a level of profit which can be achieved by making the investment. It can be concluded that the investment strategy of a company also depends on its capacity for undertaking a risk. The risk can both positively and negatively influence investment processes, i.e. it can either accelerate them or slow them down. Thus, the risk is connected with management, and should be identified as precisely as possible. It is necessary to specify its acceptable limits and the plethora of activities directed at its becoming a motivation in investment processes. $[4$, p. $21 ; 7$, p. $25-26 ; 2$, p. 43]

Investment strategy of companies is also conditioned by innovations, which are an integral part of civilization and technological progress. A tendency for implementing innovations, i.e. introducing new, useful products, technologies and services, is considered as one of major attributes of the competitiveness of companies. Companies ought to show a high level of innovation, and be responsive to market demands, introducing new products and services. [5, $\mathrm{p}$. 11-12]

Hence, establishing an optimal investment structure of a company demands accounting for all determinants and their proper choice in order to achieve the complex objectives in the sphere of company development.

Investment strategies of companies can be divided into two main groups [11, p. 144]:

$>$ investment development strategies (active, offensive)

$>$ investment non-development strategies (passive, defensive)

B. Woźniak-Sobczak and I. Hejduk point out the fact that some companies apply the strategy of moderate development, which involves cautious, selective investing. [14, p. 123 and the following; 3] The division of company investment strategies is shown in table 1. 
Table 1. Types of company investment strategies

\begin{tabular}{|c|c|c|}
\hline $\begin{array}{c}\text { TYPE OF } \\
\text { STRATEGY }\end{array}$ & $\begin{array}{c}\text { ATTITUDE TO } \\
\text { ACCEPTING RISK }\end{array}$ & RANGE OF INVESTMENT \\
\hline $\begin{array}{l}\text { Strategy of expansion } \\
\text { (active, directed at } \\
\text { development) }\end{array}$ & $\begin{array}{l}\text { Accepting high level of } \\
\text { risk }\end{array}$ & $\begin{array}{l}\text { Realization of many investment projects significantly } \\
\text { exceeds the value of annual depreciation allowance } \\
\text { (DEPRECIATION < INVESTMENTS) }\end{array}$ \\
\hline $\begin{array}{l}\text { Strategy of moderate } \\
\text { development }\end{array}$ & Limiting the level of risk & $\begin{array}{l}\text { Investment outlay is allocated to such investment projects, } \\
\text { which ensure high level of profit in a short time; in most } \\
\text { cases it is understood that the sinking fund specifies the } \\
\text { level of investment } \\
\text { (DEPRECIATION = INVESTMENTS) }\end{array}$ \\
\hline $\begin{array}{l}\text { Strategy of stagnation } \\
\text { (passive) }\end{array}$ & $\begin{array}{l}\text { Minimizing the level of } \\
\text { risk }\end{array}$ & $\begin{array}{l}\text { Minimal investment outlay, or even selling off fixed assets } \\
\text { of the company } \\
\text { (DEPRECIATION > INVESTMENTS) }\end{array}$ \\
\hline
\end{tabular}

Source: H. Hejduk, Przedsięwzięcia inwestycyjne $w$ strategii firmy; ich rola $i$ organizacja, Problemy Rozwoju Budownictwa, 1996, nr 2

Various types of investment shown in table 1 are justified by various objectives, since in most cases investing is not an objective in itself, but a result of the company's internal needs and the needs of its market environment. The differentiation of development and non-development investment strategies is possible mainly by identifying whether a business entity is pursuing a company development strategy within the framework of investment strategy.

Development investment strategy is a strategy implemented by strong business entities, willing to take a risk. The objective of investing in this kind of strategy is the expanding and strengthening of a company's presence on the market in order to gain maximized long-term profits. Large and risky, but at the same time effective investments not only facilitate a significant increase of a company's market value, but also increase its level of competitiveness. The company aims to be a leader in technique, technology and product quality and in order to achieve it, it introduces innovations while realizing large capital investments on the former and new markets.

Active development strategy involves high expenditure on investments and high level of risk. However, the risk taken by business entities is usually well calculated, i.e. it is based on the factual estimation of necessary expenditure and the objectives that can be possibly attained. The worth of the investment exceeds the worth of annual depreciation allowance accumulated in the company. It is connected with a necessity of financing a significant part of investments with the help of external capital. Thus, the investor is additionally exposed to risk connected with fluctuations of the capital market. [13, p.332]

The second group of investment strategies has been referred to as non-development (passive) strategies. They are usually minimal investments realized by a company in order to maintain its position on the market. Capital investments that help maintain company's market position are worth less than accumulated depreciation. Investments within this group of strategies usually have the character of simple reproduction or narrowed reproduction; they are usually reproductive-modernizing investments. Their aim is to modernize the assets while maintaining them on the same level. The advantages of such investments include the fact that they are realized 
on the factory floor, they facilitate technological development, and the period of their realization is relatively short, as well as the period within which the return on investments takes place.

Non-development investment strategies are oriented towards various internal determinants. Sometimes they are the result of technical, economic or organizational obligation. Generally speaking, a common feature of such investments is the fact that the pressure of external circumstances is far greater than the freedom of decision on the investor's part, who is not "strong" enough in order to overcome the pressure by acting expansively and risk an investment in development. [11, p. 146]

Apart from development investment strategies and passive investment strategies a company may realize the strategy of moderate development, which is an in-between form of investment with reference to the two already discussed. Depending on the reasons for realizing an investment, which may include maintaining the company's position on the market or maximizing profits within an average or short time, the investment outlay is either high or limited to the most effective one within a short period of time. Due to conscious limiting of the level of risk, which is characteristic of this type of investment, the level of investment outlay does not actually exceed the worth of accumulated depreciation allowance.

According to a survey on the management of capital investments in large companies, conducted by W. Grudzewski and I. Borowiecka, the business entities in question realized comparatively cautious investment strategies, which showed by the fact that the major source of financing investments was depreciation. Generated profits or bank loans were less popular as sources of financing investments. [1, p. 57]

While choosing a proper investment strategy, companies ought to take into account their financial condition, knowledge of sources and level of risk, and their capacity for accepting the risk. These factors determine whether a company realizes large, costly and risky investments which can bring a substantial profit, or choose safe investments, for which only small investment outlay is necessary, and which can bring only a comparatively small profit. 


\section{Bibliography:}

1. Borowiecka I., Grudzewski W.M., Zarządzanie inwestycjami rzeczowymi w przedsiębiorstwach w Polsce, Ekonomika i Organizacja Przedsiębiorstwa, 2002, nr 8

2. Dubik B.M., Problemy informacyjne i decyzyjne $w$ działalności inwestycyjnej, Skrypty uczelniane AE w Katowicach, Katowice 1998

3. Hejduk H., Przedsięwzięcia inwestycyjne $w$ strategii firmy; ich rola $i$ organizacja, Problemy Rozwoju Budownictwa, 1996, nr 2

4. Janasz W., Inwestycje jako czynnik restrukturyzacji przemyshu [w:] Zeszyty Naukowe Uniwersytetu Szczecińskiego, nr 172, 1996

5. Janasz W., Ksztattowanie strategii innowacji technicznych w przedsiębiorstwie, Nowator, $1999, \mathrm{nr} 7-8$

6. Łukasik G., Polityka pozyskiwania kapitału przez przedsiębiorstwa w warunkach rozwoju rynku finansowego, Prace naukowe AE w Katowicach, Katowice 1998

7. Nowak E., Pielichaty E., Poszwa M., Rachunek optacalności inwestowania, PWE, Warszawa 1999

8. Ostrowska E., Ryzyko projektów inwestycyjnych, PWE, Warszawa 2002

9. Siemińska E., Metody pomiaru $i$ oceny kondycji finansowej przedsiębiorstwa, Wydawnictwo TNOiK SWU „DOM ORGANIZATORA”, Toruń 2002

10. Stabryła A., Zarzadzanie strategiczne w teorii i praktyce firmy, PWN, Warszawa 2000

11. Towarnicka H., Strategia inwestycyjna przedsiębiorstwa przemysłowego, w: Polityka przemysłowa a strategie przedsiębiorstw, Prace naukowe AE we Wrocławiu nr 726, Wrocław 1996

12. Woźniak - Sobczak B., Funkcje kapitału w strategicznym zarzadzaniu przedsiębiorstwem, Prace naukowe AE w Katowicach, Katowice 2005

13. Woźniak - Sobczak B., $O$ aktywnym $i$ pasywnym inwestowaniu $w$ rozwój przedsiębiorstwa, [w:] Przedsiębiorstwo na rynku kapitałowym, praca pod redakcją J. Duraja, Wydawnictwo Uniwersytetu Łódzkiego, Łódź 2001

14. Woźniak-Sobczak B., Aktywne i pasywne inwestycje przedsiębiorstwa, Wydawnictwo AE w Katowicach, Katowice 2001 